Bangladesh J. Zool. 39(2): 213-221, 2011

\title{
IMPACTS OF AQUACULTURE EXTENSION ACTIVITIES ON FEMALE FISH FARMERS IN DIFFERENT AREAS OF BANGLADESH
}

\author{
Mirza Ataur Rahman, Md. Ghulam Mustafa* and Benoy Kumar Barman ${ }^{1}$ \\ Department of Fisheries, University of Dhaka, Dhaka-1000, Bangladesh
}

\begin{abstract}
The study was an initiative to assess the impacts of training supports under aquaculture extension activities provided to the female farmers involved in pond fish culture in comparison to the male farmers from different areas of Bangladesh. It is also identified that constraining factors affect the participation of female farmers in fish culture after receiving training supports under aquaculture extension program. The mean baseline fish production by the female farmers was $3.8 \pm 1.2 \mathrm{~kg} / \mathrm{dec}$ and after getting training supports it increased to $6.8 \pm 2.1$ $\mathrm{kg} / \mathrm{dec}$, which was significantly $(\mathrm{p}<0.001)$ higher $(78 \%)$ in comparison to their baseline. Overall, there was increased fish production in the ponds of the trained female farmers in comparison to their baseline year (before trained) fish production in ponds; however, their fish production was lower than that of the male farmers who received the similar sort of supports. Different factors were related to the low level of involvement of females in fish culture and the low level of fish production was related to households, social and cultural reasons. Females were busy in managing usual household works especially taking care of their children and having limited time to make regular contact with extension officers. Low level of literacy, socio-cultural barriers, higher dependency on their male counterparts, their less ability to take decision, and comparatively their poor health condition are factor constraints for their active involvement in aquaculture.

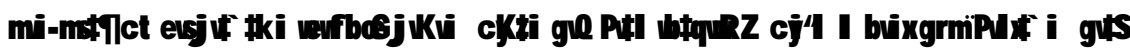

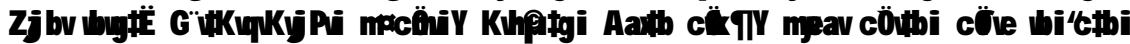

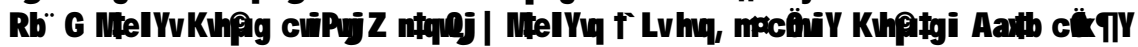

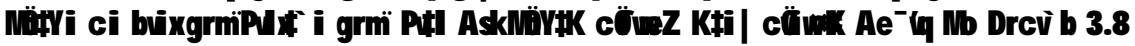

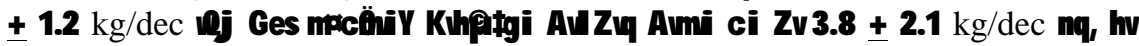

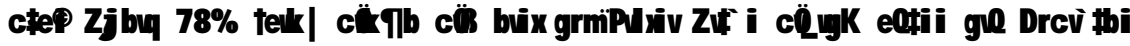

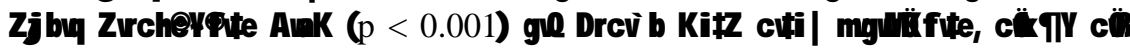

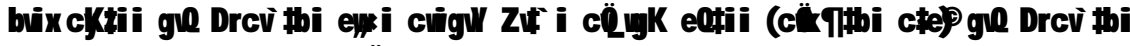

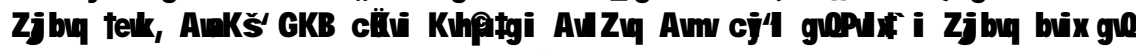

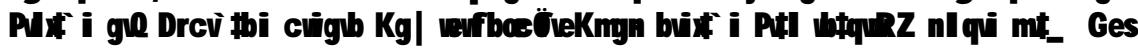

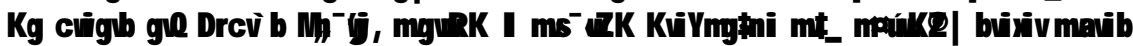

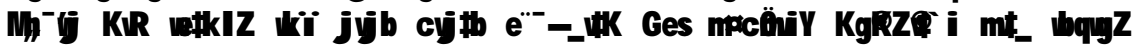

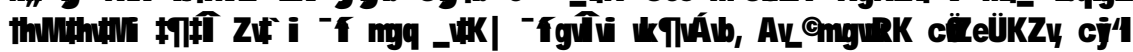

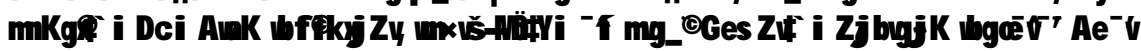

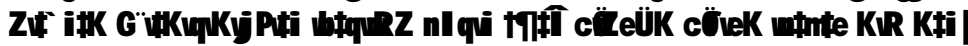

Key words: Extension, technology, constraint, malnutrition, significant, monitoring

*Corresponding author: E-mail: mgmustafabd@yahoo.com. ${ }^{1}$ The WorldFish Center, Bangladesh and South Asia Office, Banani, Dhaka-1212, Bangladesh. 


\section{INTRODUCTION}

Fisheries are playing an important role in poverty alleviation, employment generation, export earnings and in supplying major source of animal protein to the people in Bangladesh. The contribution of the sector accounts for $4.92 \%$ to the GDP, $5.71 \%$ of total export earning, employment of 1.4 million people directly and 12 million indirectly (BBS 2004). The annual fish production of the country increased from 1.781 million tons in 2001-2002 to 2.440 million tons in 2006-2007 (DOF 2006), but with the increase of population, the need of annual per capita fish consumption has declined from $18.0 \mathrm{~kg}$ to $12 \mathrm{~kg}$ (DOF 2002). Consequently, the nutritional studies showed that 0.03 million children of this country are becoming blind each year due to vitamin 'A' deficiency (Thilsted and Miah 1997). Pregnant women and young children are most at risk from deficiencies in critical micronutrients, such as fish, especially some species of small indigenous fish, and vegetables (Roos et al. 2003). To meet up this increasing demand of fish and to fulfill the micro-nutrient requirements of women and children, importance to be given in various fronts to increase the level of fish production and its uses.

This increase in the fish production is largely due to the rapid increase in fish production from aquaculture than from open water capture fisheries which is almost at the level of stagnant. Of total fish production around $39 \%$ is from aquaculture (DOF 2006). Of the aquaculture production the contribution from pond based aquaculture is considered very high. There are 2.7 million ponds covering 0.3 million ha in the country and the average fish production is 2.0-2.5 tons/ha (DOF 2005, Thomson et al. 2000). Aquaculture is helping in rural development through appreciable increase in the income of rural people and for Bangladesh, where $65 \%$ of the people are poor with having limited lands and options of income earnings, this is very important. The higher level of fish production is largely due to improvement in the use of aquaculture technologies by farmers. Extension and training supports for technologies to farmers and its uses played main role in this case. There is a great potential further to increase this present level of fish production at least two-folds through implications of improve measures to provide extension and training supports to farmers. As it is the lack of awareness, lack of know-how in technologies, constraints on financial support and less active participation of household members (males and females) are constraining to get higher level of aquaculture production. Extension and training supports provided for the promotion of aquaculture are normally not received similarly by all types of farmers and especially by female and male farmers. 
In Bangladesh, fish culture is normally considered as the activities of males, although some initiatives have been taken to involve females in small-scale aquaculture through different government projects and by NGOs. In many Asian countries, females are playing very active role in aquaculture. In China, females participate actively in different aquaculture activities including the pond digging where the rapid growth of aquaculture is attributed due to the contribution of both males and females (Baluyut 1987).

Like other agricultural production, fish culture largely depends on regular management and the participation of males and females is very important. Active participation of women in small-scale aquaculture can be an important means for their income which may meet up their necessary needs. This is important for the development of self-sustaining aquaculture by farming households in Bangladesh (Haque et al. 2000).

The present study was an initiative to look into how the extension and training supports provided to the females carrying out fish culture in ponds are bringing improvement in fish production. The studies looked more in details on what are the important factors constraining women to carry out the activities even after getting extension and training support in fish culture. The outcomes of the studies are of importance for designing effective extension and training for them to get higher level of fish production and subsequent benefits for women in the country.

\section{OBJECTIVES}

The study was an initiative to assess the impacts of aquaculture extension and training supports provided to female farmers involved in fish culture in their ponds in comparison to their male counterparts in different study areas of Bangladesh, secondly, to identify the constraints and potentials of females in participating aquaculture activities.

\section{MATERIAL AND METHODS}

In this study, a total of 20 villages was selected which are located in Dhaka, Rajshahi, Chittagong, Khulna and Barisal divisions and four villages under one Upazila were selected from each Division (Fig. 1). From these villages, 240 farmers were selected including 120 trained farmers (received training from DOF under Fourth Fisheries Project, FFP, 1999 - 2006) and 120 non-trained farmers. Again, within the trained farmers, 86 were males and 34 were females (Table 1). 


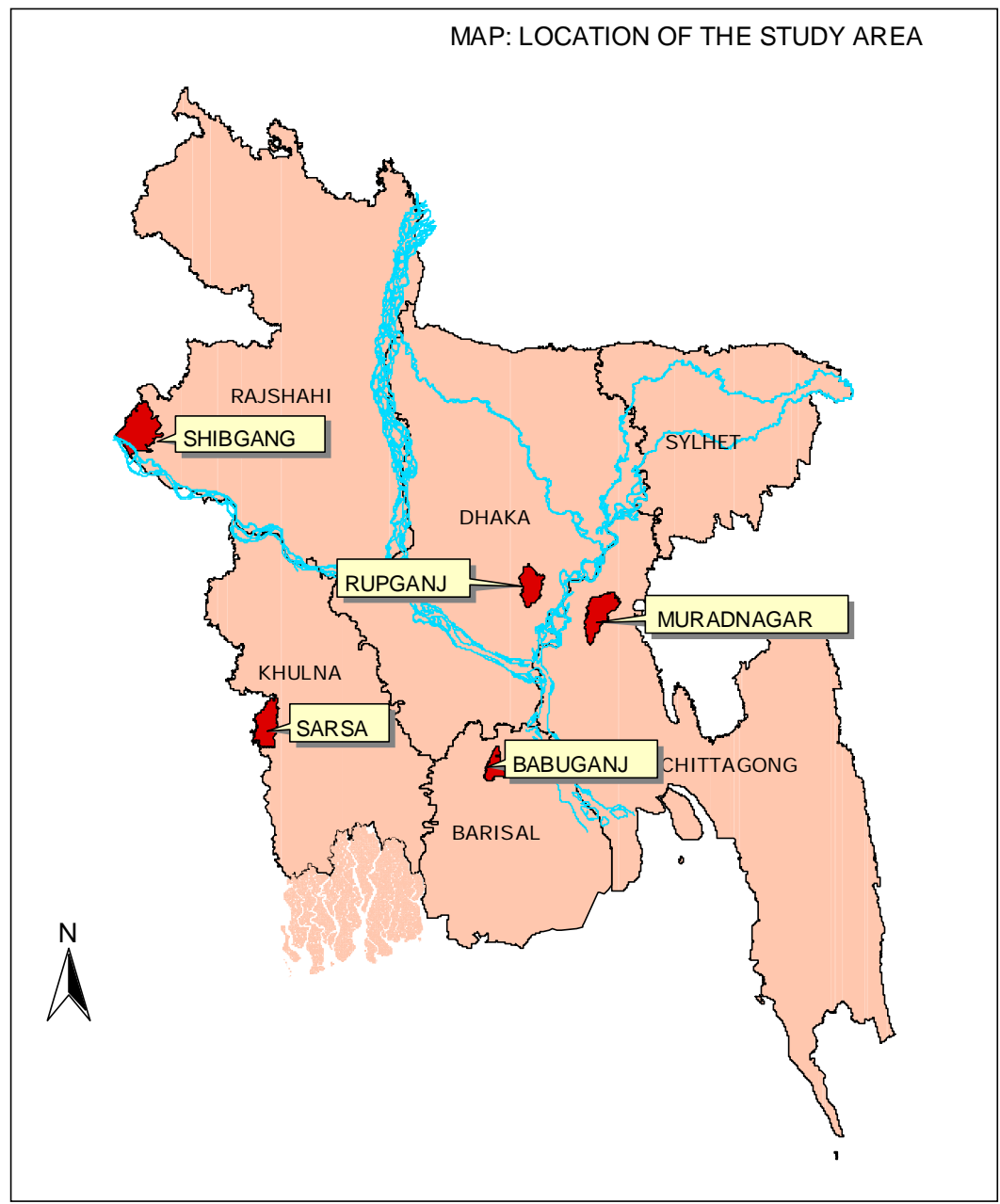

Fig. 1. Map of Bangladesh showing the study areas.

Table 1. Distribution of selected male and female trained farmers from the study areas.

\begin{tabular}{|c|c|c|c|c|c|}
\hline \multirow[t]{2}{*}{ Division } & \multirow[t]{2}{*}{ District } & \multirow[t]{2}{*}{ Upazila } & \multirow[t]{2}{*}{ Village } & \multicolumn{2}{|c|}{ Number of farmers } \\
\hline & & & & Men & Women \\
\hline Dhaka & Narayanganj & Rupganj & $\begin{array}{l}\text { Masumababad, Bhela, } \\
\text { Rrupganj, Kendua }\end{array}$ & 16 & 8 \\
\hline Rajshahi & Nawabganj & Shibganj & $\begin{array}{l}\text { Pukuria, Doulatpur, Chakla, } \\
\text { Kamalpur }\end{array}$ & 18 & 6 \\
\hline Chittagong & Comilla & Muradnagar & $\begin{array}{l}\text { Shibanipur, Raitola, Balasuta, } \\
\text { Aralia }\end{array}$ & 20 & 4 \\
\hline Khulna & Jessore & Sarsa & $\begin{array}{l}\text { Panburi, South tengrali, } \\
\text { Ramchandrapur, Ichapur }\end{array}$ & 16 & 8 \\
\hline Barisal & Barisal & Babuganj & $\begin{array}{l}\text { East khanpura, Chandapasa, } \\
\text { Uttrar- rahukati, Sigherkati }\end{array}$ & 16 & 8 \\
\hline Total & & & & 86 & 34 \\
\hline
\end{tabular}


Under the FFP training program both theoretical and practical knowledge on pre-stocking, stocking and post-stocking management techniques were offered in three days long courses. Each of the courses covered knowledge about deweeding, dike repairing, removal of predator/unwanted species, liming and prestocking fertilization; then species selection and stocking number determination, food ratio and feeding schedule preparation; finally, post-stocking fertilization, harvesting techniques and hazard management. The trained male and female farmers carried out fish culture in their respective ponds.

A structured questionnaire was prepared to collect baseline information of the farmers and a monitoring questionnaire survey was conducted for the farmers to collect the information regarding fish production and other socioeconomic data. The questionnaire developed were piloted and finalized thereafter after getting feedbacks. With assistance from the local UFOs, the baseline information of farmers was collected from 15 November 2004 to 15 February 2005. The monitoring survey was carried out for a year from March 2005 to February 2006 on monthly intervals. The baseline and monitoring data collected were then checked for accuracy and clarity, and any confusion arisen there from was corrected during the study period. The information regarding constrains of famale participation in small-scale aquaculture in the study areas were also collected from the trained female farmers at the end of the monitoring data collection period i.e. during the month of February 2006. Constraints of the female data were collected through focus group discussion (FGD). The data were statistically analysed. For data entry and analysis Microsoft Excel \& SPSS Version 11.5 were used following Imam (2005), Hasan (2002) and Mian and Miyan (1984).

\section{RESULTS AND DISCUSSION}

Fish production of trained female farmers: The baseline year mean fish production from the ponds of trained female farmers was $3.8 \pm 1.2 \mathrm{~kg} / \mathrm{dec}$ and after getting extension and training supports, the mean fish production obtained was $6.8 \pm 2.1 \mathrm{~kg} / \mathrm{dec}$ (Fig. 2). The mean level of fish production of the trained female farmers from their ponds almost doubled by getting training and extension supports from DOF. The difference in the fish production was found to be significant $(p<0.01)$. In the similar studies in other areas of Bangladesh, Sarker (2003) reported that female farmers increased almost similar levels of fish production after getting trained and receiving extension support (baseline $3.74 \pm$ $1.24 \mathrm{~kg} / \mathrm{dec}$, the fish production after support was $6.60 \pm 2.3 \mathrm{~kg} / \mathrm{dec}$ ). 
Comparison between fish production by the female and male farmers: When compared the level of fish production by the trained female farmers with their counterpart male farmers in the study areas, more differences among them in the level of production came after they have received training supports through extension activities. Although, for both of them increased fish production significantly compared to their baseline year production from the ponds, the production of the trained male farmers increased faster than the female farmers. The results showed that before receiving training supports through extension activities from DOF, the mean fish production of the male trained farmers was $4.3 \pm 1.3 \mathrm{~kg} / \mathrm{dec}$, for female it was a bit lower $3.8 \pm 1.2 \mathrm{~kg} / \mathrm{dec}$. After the extension and training supports they have received, the mean fish production of the male farmers was $8.2 \pm 2.1 \mathrm{~kg} / \mathrm{dec}$, but it was $6.8 \pm 2.1 \mathrm{~kg} / \mathrm{dec}$ (Fig. 2) for the female farmers.

Factors for the low level of fish production by the female farmers: There were 10 identified factors to constrain females in actively participate in fish culture activities to achieve similar level of higher production as the trained male farmers. Out of these factors, some were found to be the major factors and some are minor factors. As it is expected that understanding of these factors and measures to take initiatives to reduce these constraints certainly be of importance to get higher level of production and benefits by the female farmers in the county. This may also result in the opportunities for females to get income earnings and of use to improve household nutrition especially to meet up the utmost nutritional needs of pregnant women and children.

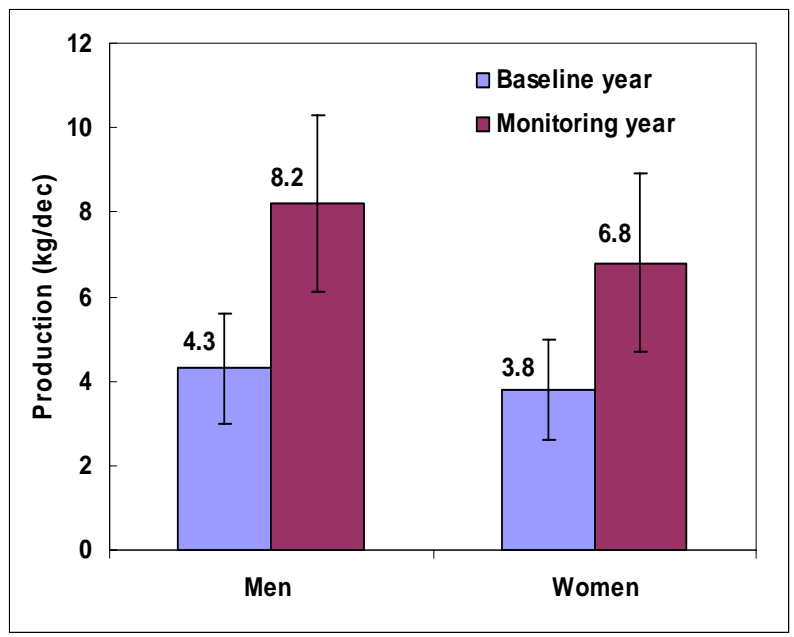

Fig. 2. Level of fish production of male and female farmers in baseline year (before extension and training support) and monitoring year after the support. 
From the study, it was found that among all the 10 constraints the highest number of respondents (99\%) unable to contact Upazila Fisheries office directly by visiting there and 99\% busy with household maintenance. DOF (2001) reported that female farmers never went to Upazila Fisheries Office. Sarker (2003) also reported that the highest numbers of respondents $(100 \%)$ had the constraints of busy with household keeping. The respondents of $90 \%$ had the constrains of educational status, social barrier to go out side $(90 \%)$ and religious taboo (77\%). Miah (2000) reported the same that the old religious villagers to go out side their house discouraged the female workers. The responders $93 \%$ of children nursing and bearing children or grand sons/daughters in training session. Varghese et al. (1994) reported that in Southern part of India, female participation in aquaculture activities is less as compared to North and Northeastern parts. Whenever females are involved, they generally take care of the pond fertilization and feeding activities in small-scale aquaculture units.

The responders $85 \%$ females dependent on husband or other male members of family for inputs purchasing and $84 \%$ females unable to take decision independently. Aireen (1992) conducted a study to identify the participation of females in household activities and to find out the problems faced in homestead farming. She reported that in case of decision making process, females in $40 \%$ farms always participated in making decisions, but males in $60 \%$ farms were found dominant in decisions making, $73 \%$ females had the constraints of sickness and malnutrition. Of the respondents $96 \%$ had the constraints of unemployment problem and $73 \%$ responders had constrains disease and malnutrition. Sarker (2003) also reported the similar percentage of farmers had constrains of sickness and malnutrition. Haque et al. (2000) reported that in homestead pond aquaculture, females and/or whole family members could play a significant role by using their unused or surplus labors. In this approach, the farm inputs would be properly utilized as well as the farmer would be self motivated to fully involve in the extension process. As a result the process will ensure the self- sustaining aquaculture for the rural resource poor farmer. Hattha et al. (1994) conducted the study in Svay Rieng province, Cambodia, small-scale aquaculture was found to add considerable amount of labor to females, children and males in the family.

In regard to aquaculture activity, females were found to be able to carry out most of the activities except harvesting. Most female headed households obtained better production, the fact that females were probably able to make decisions based on day to day observations and make immediate decisions without waiting for men approval in the family. Fish harvesting was recognized 
as the major constraints and this would impair the access of females to fish pond and harvest fish for family consumption and income generation.

It was reported that females are busy for household works and depend on their husband's decision to carry out the activities. Though the females are busy with household keeping, the percentage increment of fish production by the trained females farmers are nearly similar in comparison with the trained male farmers. Sarker (2003) reported that all females farmers were busy with household works. Ahmed (2001) reported that after training the fish farmers produced $9.89 \mathrm{~kg} / \mathrm{dec}$ fish than the base line year production $2.2 \mathrm{~kg} / \mathrm{dec}$. He concluded that targeting farmers who have ponds through extension services can push up aquaculture production and benefits them significantly. Barman et al. (2002) reported that female farmers also participated in the production of fingerlings from their rice- fish plots in North-west Bangladesh.

\section{CONCLUSION}

Present study suggested that the production of fish per unit area of pond attained almost double through the participation of the trained female farmers, which was 78 percent increase in terms of baseline production. So, it could be concluded that the imparted training among the female farmers brought a positive impact on overall fish production against the traditional system. At the same time, the economic condition of these rural women was improved. Finally, it can be said that instead of stated constraints, fish culture sector can also get momentum through the participation of trained rural females.

Acknowledgements: This paper was a part of Ph.D. thesis of the first author. The study was conducted with financial assistance from the Ministry of Science and Communication Technology, Government of the People's Republic of Bangladesh which is acknowledged gratefully. The authors also greatly acknowledge the supports provided by Dhaka University and WorldFish Center, South Asia Office.

\section{LITERATURE CITED}

AHMED, M., RAB, M.A. and GUPTA, M.V. 2001. Impact of improvement aquaculture technologies: Results of an extension program on Farming systems of Bangladesh. Asian Society, Manila, Phillipines. Asian Fisheries Science. 8(1): 327-329.

AIREEN, Q.S. 1992. An economic analysis of women's work in homestead farming in a selected area of Bangladesh. M. Sc. Thesis, Department of Agricultural Economics, Bangladesh Agricultural University, Mymensingh, Bangladesh. 87 pp.

BALUYUT, E. 1987. Women in aquaculture in Asian countries. Proceedings of the ADCP/NORAD Workshop on Women in aquaculture. ADCP Rep. 87/28. FAO, Rome, Italy. 123 pp. 
BARMAN, B. K., LITTLE, D.C. and EDWARDS, P. 2002. Small-scale fish culture in Northwest Bangladesh: A participatory appraisal focusing on the role of tilapia. In: Rural Aquaculture (eds. P Edwards, D C Little and H Demaine). CABI Publishing, UK. pp 227-244.

BBS. 2004. Statistical year book of Bangladesh 2003, Bangladesh Bureau of statistics (BBS), Ministry of Planning, Dhaka, Bangladesh.

DOF. 2001. An assessment of the Socio-economic background of farmers trained in the Aquaculture Extension and Training Component. Project Management Unit, Dept. of Fisheries, Matshaya Bhaban, Park Avenue, Ramna, Dhaka. 22 pp.

DOF. 2002. Fish fortnight souvenir 2002. Department of Fisheries (DOF), Dhaka, Bangladesh. 2, 3 pp.

DOF. 2005. Fishery statistical yearbook of Bangladesh 2005-2006. Fisheries Resources Survey System (FRSS), Department of Fisheries, Dhaka, Bangladesh. 1, 42 pp.

DOF. 2006. Fishery statistical yearbook of Bangladesh 2005-2006. Fisheries Resources Survey System (FRSS), Department of Fisheries, Dhaka, Bangladesh. 1, 42-47 pp.

HAQUE, M.T., AHMED, M. and FORBES, A. 2000. Sustainable aquaculture extension approach in Bangladesh: A perspective of Greater Noakhali Aquaculture Extension Project. Paper presented at the Workshop on Aquaculture Extension: Impacts and Sustainability. Department of Fisheries/ICLARM Workshop. 11 May 2000, Dhaka, Bangladesh. 18 pp.

HASAN, T. 2002. Introduction to biometry. pp. 77-124.

HATHA, A.N., NARATH, S. and GREGORY R. 1994. A study of the roles and responsibilities of Cambodian women and children in small scale aquaculture. Paper presented at the National Workshop on Women in Cambodian Fisheries. 7-9 November 1994, Bati Fisheries Station, Prey Veng Province, Cambodia.

IMAM, M.F. 2005. SPSS for Windows. pp. 161-246.

MAZID, M.A. 2002. Development of fisheries in Bangladesh: Plans and strategies for income generation and poverty alleviation. Momin Offset Press, Dhaka, Bangladesh.1, 11, 176, pp.

MIAH, T.H. 2000. Consultancy Report on Agricultural Economics. Winrock International, ARMP(TA), Dhaka, Bangladesh and Kranti Associates Ltd., Dhaka, Bangladesh. pp 4, 27-32.

MIAN and MIYAN. 1984. An Introduction to Statistics. pp. 703-746.

ROOS, N., THILSTED, S.H. and WAHAB, M.A. 2002. Culture of small indigenous fish species in seasonal ponds in Bangladesh: The potential for production and impact on food and nutrition security. In: Rural Aquaculture (eds. P Edwards, D C Little and H Demaine), CABI Publishing, UK, pp. 245-252.

SARKER, A.K. 2003. Performance analysis of the trained fish farmers and gender participation in Small- scale aquaculture. pp. 25-110.

THILSTED and MIAH, T.H. 1997. Paper presented at the national workshop on children suffering from nutrition deficiency in Bangladesh-at BARC Centre, 17 Nov, 1997.

THOMPSON, P.M., SULTANA, P., NURUZZAMAN, M. and KHAN, A.K.M.F. 2000. Impacts of aquaculture extension on pond operators and the rural community. Paper presented in the Tenth Biennial Conference of the International Institute of Fisheries Economics and Trade (IIFET). 10-14 July 2000, ICLARM, Dhaka, Bangladesh. 9 pp.

VARGHESE, T.J. and NANDEESHA, M.C. 1994. Women in Indian fisheries. Proceedings of the Workshop on Women in Indian Fisheries, 27 May 1990 (ed. R G Sudhindra). Special Publication 8. Asian Fisheries Society, Indian Branch, Mangalore, India. 51 pp. 